\title{
Production of Whey Protein-Based Aggregates Under Ohmic Heating
}

\author{
Ricardo N. Pereira ${ }^{1} \cdot$ Rui M. Rodrigues ${ }^{1}$. Óscar L. Ramos ${ }^{1,2}$ - F. Xavier Malcata ${ }^{2,3}$. $^{2}$ \\ José António Teixeira ${ }^{1} \cdot$ António A. Vicente ${ }^{1}$
}

Received: 24 September 2015 / Accepted: 17 November 2015 / Published online: 28 November 2015

(C) Springer Science+Business Media New York 2015

\begin{abstract}
Formation of whey protein isolate protein aggregates under the influence of moderate electric fields upon ohmic heating $(\mathrm{OH})$ has been monitored through evaluation of molecular protein unfolding, loss of its solubility, and aggregation. To shed more light on the microstructure of the protein aggregates produced by $\mathrm{OH}$, samples were assayed by transmission electron microscopy (TEM). Results show that during early steps of an $\mathrm{OH}$ thermal treatment, aggregation of whey proteins can be reduced with a concomitant reduction of the heating charge - by reducing the come-up time (CUT) needed to reach a target temperature - and increase of the electric field applied (from 6 to $12 \mathrm{~V} \mathrm{~cm}^{-1}$ ). Exposure of reactive free thiol groups involved in molecular unfolding of $\beta$-lactoglobulin $(\beta-\lg )$ can be reduced from 10 to $20 \%$, when a CUT of $10 \mathrm{~s}$ is combined with an electric field of $12 \mathrm{~V} \mathrm{~cm}^{-1}$. Kinetic and multivariate analysis evidenced that the presence of an electric field during heating contributes to a change in the amplitude of aggregation, as well as in the shape of the produced aggregates. TEM discloses the appearance of small fibrillar aggregates upon the influence of $\mathrm{OH}$, which have recognized potential in the functionalization of food protein networks. This study demonstrated that $\mathrm{OH}$ technology can be used to tailor denaturation and aggregation behavior of whey
\end{abstract}

Ricardo N. Pereira

rpereira@deb.uminho.pt; rncpereira@hotmail.com

1 CEB - Centre of Biological Engineering, University of Minho, 4710-057 Braga, Portugal

2 LEPABE - Laboratory of Engineering of Processes, Environment, Biotechnology and Energy, University of Porto, Rua Dr. Roberto Frias, P-4200-465 Porto, Portugal

3 Department of Chemical Engineering, University of Porto, Rua Dr. Roberto Frias, P-4200-465 Porto, Portugal proteins due to the presence of a constant electric field together with the ability to provide a very fast heating, thus overcoming heat transfer limitations that naturally occur during conventional thermal treatments.

Keywords Whey protein isolate $\cdot$ Ohmic heating $\cdot$ Electric fields · Protein solubility · Aggregation kinetics · Protein fibrillar aggregates

\section{Introduction}

Whey protein-based matrices are now widely used in the formulation of food products in the form of pure individual fractions or as whey ingredients such as whey protein concentrate (WPC) and whey protein isolate (WPI). These ingredients are dominated by techno-functional properties of $\beta$-lactoglobulin (Lefevre et al. 2005), presenting high nutritional and biological value (i.e., digestibility, amino acid pattern, and sensory characteristics) but also showing the ability to form hydrogels (Bryant and McClements 1998; Madureira et al. 2007; Nicolai et al. 2011).

Protein hydrogels are defined as three-dimensional hydrophilic networks that can swell in aqueous conditions and entrap a large amount of water, while maintaining a stable network structure (Chen et al. 2006; Qiu and Park 2012). Gelation of proteins is a complex process that usually requires a driving force to unfold the native protein followed by a chemical or physical aggregation process to yield a threedimensional protein network. The driving force for gelation can be a physical process, such as heat or pressure, or a chemical process, such as acid, ionic, or enzymatic reaction (Stokes 2012; Dissanayake et al. 2013). Among these, the most common method for forming food gels with globular proteins is by heating (Foegeding 2006; Nicolai et al. 2011). It is known that 
heating at relatively high temperatures $\left(>60{ }^{\circ} \mathrm{C}\right)$ results in thermal denaturation of globular whey proteins (Pereira et al. 2011; Nicolai and Durand 2013). Depending on the factors such as balance between attractive and repulsive interactions between denatured proteins, molecular architecture, and environment aqueous conditions (e.g., $\mathrm{pH}$ and ionic strength), globular whey proteins can remain as individual molecules or form different kinds of protein aggregates (Cornacchia et al. 2014). These aggregates are the "building blocks" needed for the development of food-grade nano- and micronetwork hydrogel structures. Whey protein aggregation has then a strong impact upon the production and rheological performance of gels in food materials (Kavanagh et al. 2000).

WPI, due mostly to the presence of $\beta$-lactoglobulin $(\beta-\mathrm{lg})$, can form particulate networks in the $\mathrm{pH}$ range of $4-6$, while fine-stranded networks are formed above and below this region (Stading et al. 1992; Ikeda and Morris 2002; Nicolai et al. 2011). Production and development of $\beta-\lg$ and WPI hydrogels have been studied extensively during the latest decades (Bryant and McClements 1998; Kavanagh et al. 2000; Lefevre and Subirade 2000; Phan-Xuan et al. 2013; Stading and Hermansson 1990, 1991; Stading et al. 1992). This interest arises with the possibility of designing whey protein hydrogels' size from micrometers to nanometers, thus allowing their incorporation in foods to impart desirable textural properties. These structures may also be used to protect and improve delivery of value-added bioactive compounds through microencapsulation and nano-encapsulation techniques (Augustin 2003; Bhopatkar et al. 2012; Chen and Subirade 2007; Chen et al. 2006; Gunasekaran et al. 2007; Livney 2010; Nicolai et al. 2011; Schmitt et al. 2009). However, the mechanism of protein unfolding, aggregation, and gelation is rather complex. Gelation depends not only on $\mathrm{pH}$ and ionic strength but also on other conditions prevailing in the aqueous solution (i.e., ionic calcium content, fat content, presence of lactose, and protein composition/concentration) and heating treatments (Dalgleish and Banks 1991; Law and Leaver 2000; Nicorescu et al. 2008; Tuan et al. 2011; Verheul et al. 1998; Anema and Li 2003). For instance, it was shown that the type of heating method (direct or indirect) used for protein denaturation should not be overlooked. Recent studies showed that ohmic heating can influence unfolding, denaturation, and eventually size of the whey protein aggregates, and thus the viscoelastic dynamic behavior of thermoset WPI gels (Pereira et al. 2010; Pereira et al. 2011). During ohmic heating, a moderate and alternating electric current passes through the product to be heated, which behaves as a resistor in an electrical circuit, allowing generation of internal heat in accordance with Joule's law (De Alwis and Fryer 1990). Ohmic heating seems to offer a great potential for modulation of WPI micro- and nano-hydrogels' properties, as well as development of water-soluble controlled delivery targeted for nutraceutical and functional food compounds (Rodrigues et al.
2015). However, only a few scientific and technical reports have focused on the effects of this technology upon whey ingredients or enriched fractions of $\beta-\lg$, which is the most susceptible whey protein to heat treatments during thermal pasteurization or sterilization (Rodrigues et al. 2015). The ability that ohmic heating has in providing a fast and uniform heating, together with its inherent electrical effects, should be exploited seeking processed whey protein products of high quality and distinctive technological functionalities. Therefore, the purpose of this study was to characterize early steps of protein WPI denaturation and aggregation under the influence of ohmic heating treatments by combining different thermal and electrical effects.

\section{Experimental}

\section{Materials}

WPI powder (Lacprodan DI-9212) was kindly supplied by Arla (Arla Foods, Viby, Denmark). In accordance with information provided by the supplier, WPI powder was essentially free of fat $(\max 0.2 \%$ ) and lactose $(\max 0.5 \%)$. Protein composition, determined by reversed-phase high-performance liquid chromatography (RH-HPLC) as described elsewhere (Rodrigues et al. 2015), was as follows: $\alpha$-lactalbumin $(\alpha$ lac) $22.8 \%$, bovine serum albumin (BSA) $1.7 \%, \beta-\lg \mathrm{A}$ $44 \%, \beta-\operatorname{lgB} 30.7 \%$, and immunoglobulins (IG) $1.1 \%$, on a protein basis. All chemicals used were of analytical grade.

\section{Preparation of WPI Solutions}

WPI solutions at $3 \%(w / v)$ were prepared by dispersing the WPI powder in ultrapure water (with a resistivity of $18.2 \mathrm{M} \Omega \mathrm{cm}$ ) with $0.1 \mathrm{~mol} \mathrm{~L}^{-1}$ of $\mathrm{NaCl}$ (Sigma-Aldrich, Madrid, Spain). This WPI solution was then stirred continuously overnight at refrigeration temperature $\left(5^{\circ} \mathrm{C}\right)$ to ensure full rehydration, and $\mathrm{pH}$ was adjusted to 3.0 with $1 \mathrm{~mol} \mathrm{~L}^{-1}$ of $\mathrm{HCl}$ (Merck KGaA, Darmstadt, Germany). The solution prepared with $0.1 \mathrm{~mol} \mathrm{~L}^{-1}$ of $\mathrm{NaCl}$ allowed always an optimal starting electrical conductivity (of $1000 \mu \mathrm{S} \mathrm{cm}^{-1}$ ) for the ohmic heating effect to take place.

\section{Conventional Heating}

Experiments were performed in a double-walled waterjacketed glass reactor vessel $(30 \mathrm{~mm}$ of internal diameter and $100 \mathrm{~mm}$ in height), as reported previously (Pereira et al. 2010). Treatment temperature was controlled by circulating thermostabilized water from a bath set at the same temperature as that selected for the treatment to avoid thermal abuses. A magnetic stirrer (size of $0.5 \mathrm{~cm}$ ) at $150 \mathrm{rpm}$ allowed to homogenize the $30 \mathrm{~mL}$ of WPI solution and thus improve heat 
transfer during the heating cycle. Temperature was measured with a type $\mathrm{K}$ thermocouple (temperature precision of $\pm 1{ }^{\circ} \mathrm{C}$; Omega Engineering, Inc., Stamford, CT, USA), placed at the geometric center of the sample volume, and connected to a data logger (USB-9161, National Instruments Corporation, Austin, TX, USA).

\section{Ohmic Heating}

Treatments were performed in a cylindrical glass tube of $30 \mathrm{~cm}$ total length and an inner diameter of $2.3 \mathrm{~cm}$, with two stainless steel electrodes isolated at each edge with Teflon caps as described elsewhere (Pereira et al. 2010; Pereira et al. 2011). A gap between the electrodes of $5 \mathrm{~cm}$ (the treatment chamber) was used for the experiments, and the supplied voltage ranged from 0.3 to $170 \mathrm{~V}$. The supplied voltage, and consequently the actual temperature, was controlled through the use of a function generator $(1 \mathrm{~Hz}-25 \mathrm{MHz}$ and 1 to $10 \mathrm{~V}$; Agilent 33220A, Penang, Malaysia) connected to an amplifier system (Peavey CS3000, Meridian, MS, USA). During the experiments, the nominal electric field was varied through the function generator to adjust the voltage supplied and simulate the thermal history of samples observed during conventional heating experiments or to promote instantaneous heating; for each experiment, electric fields of 6 and $12 \mathrm{~V} \mathrm{~cm}^{-1}$ were applied during the holding heating phase. To exclude shearing conditions, as a potential reason for different aggregation behavior of whey protein, sample volume and stirring conditions were identical, as described previously for conventional heating treatments.

\section{Heating Conditions}

WPI dispersions of $30 \mathrm{~mL}$ were heated through conventional heating and ohmic heating $(\mathrm{OH})$ at temperatures of $90{ }^{\circ} \mathrm{C}$. After a heating come-up time (CUT) period (to raise temperature from 20 to $90{ }^{\circ} \mathrm{C}$ ), the treatment temperature was held constant (holding) for $5 \mathrm{~min}$. Given the potential that $\mathrm{OH}$ has in achieving very quickly the required treatment temperatures, the influence of fast CUT on the aggregation patterns of whey protein dispersions was also evaluated. Two different CUT were used during the experiments-i.e., $100 \mathrm{~s}$ (applicable for conventional and $\mathrm{OH}$ ) and $10 \mathrm{~s}$ (only applicable for $\mathrm{OH}$ ). During the holding phase, unheated (control) and heated samples $(1 \mathrm{~mL})$ were removed at appropriate time intervals and cooled immediately in ice for $5 \mathrm{~min}$. Non-thermal effects were evaluated by a close coincidence of the temperature profiles (CUT and holding) during $\mathrm{OH}$ treatments performed at different field strengths (Fig. 1).

\section{Turbidity Measurement}

Transparency of treated and untreated WPI samples was evaluated at $500 \mathrm{~nm}$ in 1-cm-path-length plastic cuvettes, using a double-beam UV-VIS spectrophotometer (V-560, Jasco Inc., Tokyo, Japan) at room temperature $\left(25^{\circ} \mathrm{C}\right)$.

\section{Protein Solubility}

Apparent whey protein solubility was followed by means of a soluble tryptophan fluorescence value on the $\mathrm{pH} 4.6$ soluble supernatant, as described before (Pereira et al. 2011; Rodrigues et al. 2015). Samples (1 mL) from heated and unheated (control) solutions were adjusted to $\mathrm{pH} 4.6$ to precipitate denatured whey proteins, via the addition of $1.0 \mathrm{~mL}$ of a 1:1 mixture of $0.83 \mathrm{~mol} \mathrm{~L}^{-1}$ acetic acid and $0.2 \mathrm{~mol} \mathrm{~L}^{-1}$ sodium acetate. Then, centrifugation was carried out at $15,558 \mathrm{~g}$ for $5 \mathrm{~min}$, using a microcentrifuge (Mikro 120, Andreas Hettich GmbH \& Co.KG, Tuttlingen, Germany). Tryptophan fluorescence spectra of the supernatant fraction were recorded in a fluorescence spectrophotometer (FP 9200, Jasco Inc., Tokyo, Japan), with excitation and emission monochromators at 290 and $340 \mathrm{~nm}$, respectively. Percentage of soluble protein was then calculated from a predetermined calibration curve based on the fluorescence emission of standard $\beta$-lg.

\section{Determination of Accessible Sulfhydryl Groups}

Accessible free sulfhydryl (SH) groups were determined in unheated (control) and heated WPI solutions at appropriate time intervals, immediately after processing, using the procedures developed in previous work (Pereira et al. 2010). Ellman's DTNB (5,5'-dithiobis-(2-nitrobenzoicacid)) method, modified to react specifically with free SH in milk proteins (Patrick and Swaisgood 1976), was adapted for the determination of reactive SH groups in WPI solutions. DTNB reacts with thiol compounds to produce $1 \mathrm{~mol}$ of $p$-nitrothiophenol anion $\mathrm{mol}^{-1}$ of thiol (Ellman 1959). A 100- $\mu$ L sample of WPI solutions (unheated and heated) was diluted to $1 \mathrm{~mL}$ with phosphate buffer (5 mmol L ${ }^{-1}, \mathrm{pH} 8.0$ ) and adjusted to $\mathrm{pH} 8.0$ with $1 \mathrm{~mol} \mathrm{~L}^{-1}$ $\mathrm{NaOH}$ (Merck KGaA, Darmstadt, Germany); for the determination of total SH groups, urea $(8 \mathrm{M})$ was added to phosphate buffer (Sava et al. 2005). To the aforementioned buffers was added $12 \mu \mathrm{L}$ of $5 \mathrm{mmol} \mathrm{L}^{-1}$ DTNB (Sigma-Aldrich, Madrid, Spain), and color development was allowed to proceed for $40 \mathrm{~min}$. Residual protein aggregates were removed by centrifuging at $15,558 \mathrm{~g}$ for $30 \mathrm{~min}$ at room temperature. The clear solution at the center of the centrifuge tube was removed with a syringe, and absorbance was read on a microplate reader (Synergy HT, Biotek U.S., Winooski, VT, USA) at $412 \mathrm{~nm}$. The concentration of free SH groups in the sample was calculated using a calibration curve with cysteine. For this purpose, a standard curve was constructed with a standard solution of 
Fig. 1 Example of thermal histories applied at different electric field strengths through conventional heating $\left(0 \mathrm{~V} \mathrm{~cm}^{-1}\right)$ and ohmic heating treatments $(6$ and $\left.12 \mathrm{~V} \mathrm{~cm}^{-1}\right)$, using different CUT (10 and $100 \mathrm{~s})$ to raise the temperature to $90^{\circ} \mathrm{C}$, set as holding temperature

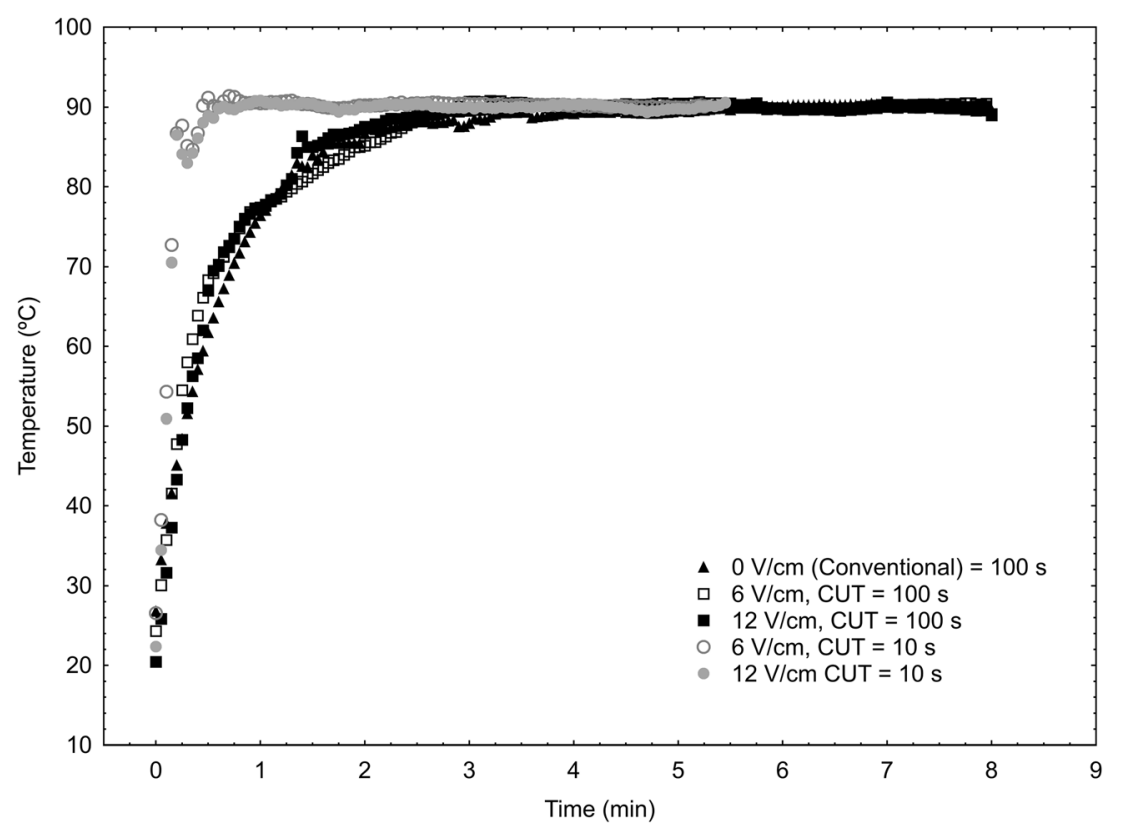

cysteine at $\mathrm{pH} 8.0$ in the range of 12 to $95 \mu \mathrm{mol} \mathrm{L}^{-1}$. Free $\mathrm{SH}$ groups were expressed as a percentage of the total SH groups.

\section{Particle Size Analysis}

Particle size measurements were made by dynamic light scattering (DLS) using a Zetasizer Nano (ZEN 3600, Malvern Instruments Ltd., UK), equipped with a $\mathrm{He}-\mathrm{Ne}$ laser of $632.8 \mathrm{~nm}$ and $4 \mathrm{~mW}$. Measurements of the dynamics of the scattered light were collected applying backscatter detection NIBS (non-invasive backscatter) at $173^{\circ}$, which reduces multiple scattering and allows higher concentrations to be measured. Average diffusion coefficients were determined by the method of cumulant fit and were translated into average particle diameters ( $Z$-value) using the Stokes-Einstein relationship (Anema and Li 2003). Samples of $1 \mathrm{~mL}$ were poured into disposable sizing cuvettes and measurements were carried out (at least) in triplicate. The temperature of the cell was maintained at $25 \pm 0.5^{\circ} \mathrm{C}$ during the measurements.

\section{Transmission Electron Microscopy}

Transmission electron microscopy (TEM) imaging was conducted on a Zeiss EM 902A (Thornwood, NY, USA) microscope, at accelerating voltages of 50 and $80 \mathrm{kV}$. A drop of sample was deposited onto a carbon support film mounted on a copper grid. The excess product was removed after 2 min using a filter paper. The samples were negatively stained for $15 \mathrm{~s}$ by a droplet of aqueous solution of $3 \%$ uranyl acetate. TEM images were processed using the ImageJ software package (v.1.44 for Windows) to enhance contrast and evaluate the protein aggregates formed.

\section{Statistical Analysis}

All statistical analyses involving experimental data were performed using Statistica package software version 10.0.228.8 (StatSoft Inc., Tulsa, OK, USA). Statistical significance was determined by Student's $t$ and Tukey's tests, using 0.05 as the preselected level of significance. Unless otherwise stated, all experiments were run at least in duplicate.

\section{Results and Discussion}

\section{Reactivity of Free SH Groups}

$\beta$-lg exists as a non-covalently linked dimer stabilized by hydrogen bonds, in which each monomer has one free $\mathrm{SH}$ group (i.e., Cys121) hidden in the hydrophobic core of the folded protein (de Wit 1998). At relatively high temperatures (above $60{ }^{\circ} \mathrm{C}$ ), the $\beta$-lg molecule undergoes denaturation and conformational transitions, exposing the free SH group of hydrophobic amino acids, initially deeply buried in the native protein conformation. This free SH becomes available for covalent disulfide bonds and disulfide interchange reactions, which together with non-covalent interactions (i.e., ionic, van der Waals, and hydrophobic) produce $\beta$-lg aggregates. Once the amount of $\beta$-lg in WPI used in this study exceeds $70 \%$, it can be assumed that the reactivity or availability of free SH during heat treatment is governed primarily by this protein (Stanciuc et al. 2012). Recent research has shown that unmasking of SH in WPI is clearly observable during early stages of heating due to unfolding and structural transitions of $\beta$-lg that precede covalent disulfide bonding of unfolded proteins (Rodrigues et al. 2015). The unfolding behavior, 
measured by the changes in the exposure of free SH groups, is apparent in Fig. 2a. Both conventional and $\mathrm{OH}$ treatments induced unfolding, rendering free SH groups more accessible for interaction with DTNB. The maximum extent of SH availability, expressed as a percentage of the total SH groups of untreated WPI, ranged between 70 and $90 \%$ and was observed after heating for $5 \mathrm{~min}$ without the presence of an electric field (conventional heating, $0 \mathrm{~V} \mathrm{~cm}^{-1}$ ). As expected, $\mathrm{OH}$ treatments with a CUT of $10 \mathrm{~s}$ tended to lessen the exposure of free SH groups; this was noticed at the sampling moment at which treatment temperature (i.e., $90^{\circ} \mathrm{C}$ ) is reached $(0 \mathrm{~min})$. It has been recently reported that lessening the heating load can contribute to a reduction of whey protein denaturation, giving rise to distinctive kinetic and thermodynamic parameters (Pereira et al. 2011). In general, exposure of SH was less favored when treatments at $12 \mathrm{~V} \mathrm{~cm}^{-1}$ with a CUT of $10 \mathrm{~s}$ were applied $(p<0.05)$, resulting in a decrease of 10 to $20 \%$ of free SH groups when compared with conventional

a

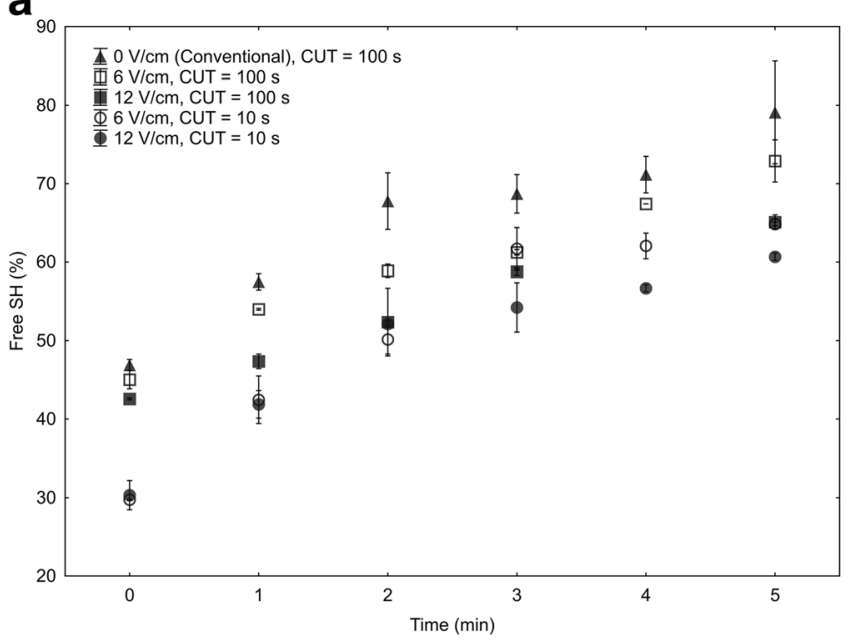

treatments (at $0 \mathrm{~V} \mathrm{~cm}^{-1}$ ). This highlights not only the importance of reducing the total time of heating treatment but also the effect of increasing the electric field applied, as well as the combination of the two effects. An additional non-thermal effect may be explained by unfolding transitions or conformational disturbances of $\beta$-lg promoted during its denaturation pathways or by a possible enhancement of oxidative elimination of cysteine to dehydroalanine, also known by a desulfurization (Chalker et al. 2011). Despite a trend for reduction of free $\mathrm{SH}$ being observed when the other $\mathrm{OH}$ treatments were applied (i.e., $6 \mathrm{~V} \mathrm{~cm}^{-1}$ for CUT of 10 and $100 \mathrm{~s}$ and $12 \mathrm{~V} \mathrm{~cm}^{-1}$ for a CUT of $100 \mathrm{~s}$ ), these effects were not statistically significant $(p>0.05)$.

\section{Aggregation}

The relationship between the loss of solubility of protein monomers and the formation of protein aggregates, turbidity,

b

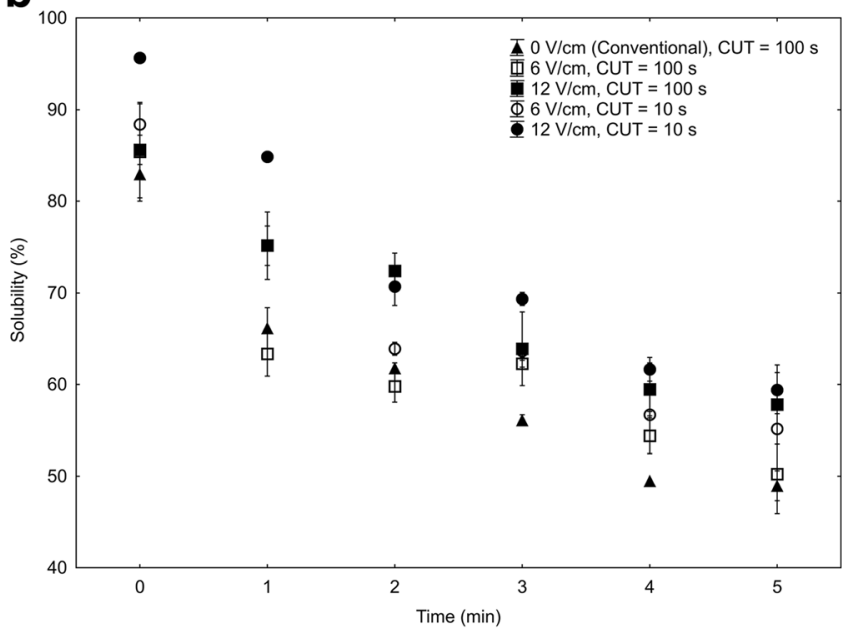

C

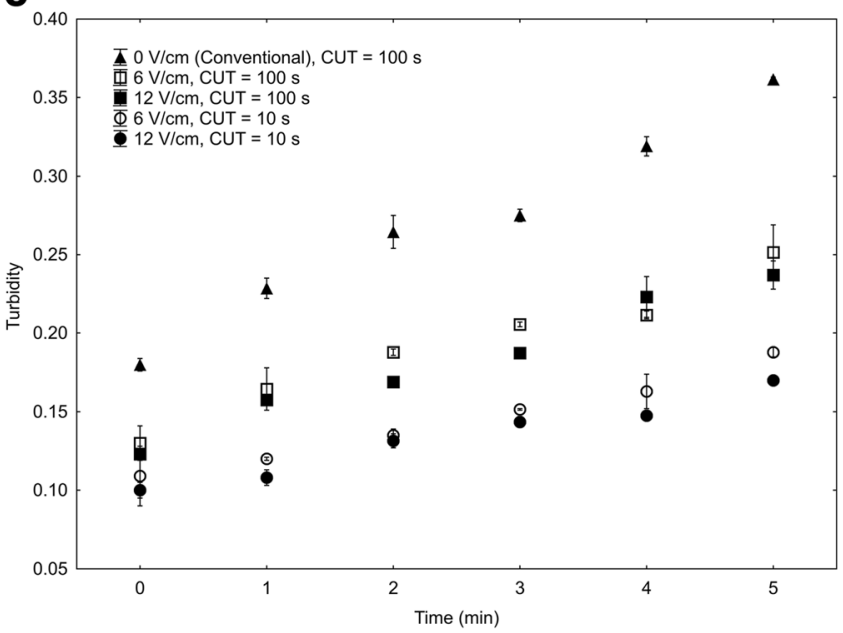

Fig. 2 Time-dependent changes in a surface exposure of SH groups, b protein solubility, and c turbidity of WPI solutions $(3 \% \mathrm{w} / v)$ when heated at $90{ }^{\circ} \mathrm{C}$, under conventional heating $\left(0 \mathrm{~V} \mathrm{~cm}^{-1}\right)$ and ohmic heating using different CUT (10 and 100 s) and electric field strengths $\left(6\right.$ and $\left.12 \mathrm{~V} \mathrm{~cm}^{-1}\right)$ 
and protein aggregate size was explored in this study. The loss of solubility of whey proteins at their isoelectric point (pI) is considered a reliable predictor of protein denaturation (Law and Leaver 2000; Pereira et al. 2011; Stanciuc et al. 2012). Figure $2 \mathrm{~b}$ shows that all treatments resulted in loss of protein solubility (from approximately 90 to $45 \%$ ) due to the irreversible denaturation of protein. Loss of protein solubility seems to be flattened when $\mathrm{OH}$ treatments are applied, particularly during the first 2 min of heating. However, this effect was only significant $(p<0.05)$ when a CUT of $10 \mathrm{~s}$ and an intensity of $12 \mathrm{~V} \mathrm{~cm}^{-1}$ were combined. After $5 \mathrm{~min}$ of heating, no significant differences on protein solubility $(p>0.05)$ were found among all the treatments. These results are in agreement to those reported elsewhere (Pereira et al. 2011), in which it has been observed that $\mathrm{OH}$ treatments at $90{ }^{\circ} \mathrm{C}$ with fast CUT (5 to $37 \mathrm{~s}$ ) presented ca. 15$30 \%$ more native soluble protein than treatments at $0 \mathrm{~V} \mathrm{~cm}^{-1}$ (conventional heating) with longer CUT, during early stages of heating. In contrast, from Fig. $2 c$, it is possible to observe that $\mathrm{OH}$ treatments led always to a lower increase in turbidity $(p<0.05)$, even under the most severe heat conditions applied-i.e., $5 \mathrm{~min}$ at $90{ }^{\circ} \mathrm{C}$ with a CUT of $100 \mathrm{~s}$ - corresponding to the ones used during conventional heating $\left(0 \mathrm{~V} \mathrm{~cm}^{-1}\right)$. Turbidity measures scattered visible light and thus depend on the number, concentration, and size of aggregated particles, as well as on their interactions (Soos et al. 2009). The turbidity of the treated WPI solutions was proven to be highly dependent on both the presence of electric fields (independently of their intensity) and the applied heating CUT. Thus, differences found between $\mathrm{OH}$ and conventional heating treatments under identical thermal conditions can be explained by the fact that type and number (or size) of aggregates produced varied under the electrical effects of $\mathrm{OH}$ (Hoffmann et al. 1996; Prabakaran and Damodaran 1997). When CUT is reduced from 100 to $10 \mathrm{~s}$, differences towards conventional heating (at $0 \mathrm{~V} \mathrm{~cm}^{-1}$ ) are even more noticeable independently of the electric field applied.

Denaturation of whey proteins is a very complex process, in which changes in the conformation and unfolding of protein molecules are followed by irreversible aggregation reactions. Loss of protein solubility has increased solution turbidity due to formation of large protein aggregates. Figure 3 shows timedependent changes in the hydrodynamic diameter of the protein aggregates ( $Z$-average size). $Z$-average size is the primary and most stable parameter produced by the dynamic light scattering cumulant analysis. Its evaluation is beneficial when comparing different treatments performed on the same sample matrix seeking for differences in aggregation quality patterns rather than for descriptive purposes (Gordon and Pilosof 2010). Assuming an exponential aggregation growth, data points were fitted using an exponential growth function
(Eq. 1) that relates protein aggregation (i.e., increase of $Z$ average value) to time:

$Z=Z_{0}+a \cdot\left(e^{k \cdot t}-1\right)$

were $a$ is related with particle size growth, giving a measure of the extent of aggregation; $Z_{0}$ corresponds to the protein particle size when temperature reaches $90{ }^{\circ} \mathrm{C}$ (i.e., 0 min of holding); and $k$ is the apparent rate of aggregation (Ziegler et al. 2006). Kinetic parameters obtained through the fitting procedure for each treatment applied are presented in Table 1. These kinetic parameters were highly significant $(p<0.001)$, and their fit to the experimental data was satisfactory since all $R^{2}$ values ranged from 0.96 to 0.97 . However, the model was not well adjusted to the data from treatments at $12 \mathrm{~V} \mathrm{~cm}^{-1}$ and CUT of $10 \mathrm{~s}$. These conditions may have impaired the onset of protein polymerization, which was reflected by a lag time observed prior to aggregation transition. The differences in $k$ value were not statistically significant $(p>0.05)$ between all treatments, thus giving the indication that the rate of protein aggregation was essentially governed by the thermal conditions, independently of CUT and electric field applied. However, the presence of an electric field has changed significantly $(p<0.05)$ the kinetic parameter $a$, which corresponds to the extent or growth of aggregation. From Table 1, a trend can be easily observed in which $k$ increases and $a$ decreases with increasing electrical intensity of the $\mathrm{OH}$ treatment for each CUT applied. This indicates that $\mathrm{OH}$ is eventually giving rise to protein aggregates of different sizes or shapes, thus contributing to a lower extent of aggregation, when compared with the conventional heating treatment. These results correlated well with the loss of protein solubility measurements. Figure 4 shows the relationship between loss of protein solubility and the concomitant increase in protein particle size, for all applied treatments. In fact, conventional heating treatments (no electric field applied, $0 \mathrm{~V} \mathrm{~cm}^{-1}$ ) seem to be well characterized by a regression representing an exponential increase in protein particle size - i.e., from 100 to $300 \mathrm{~nm}$, when protein solubility decreases from 80 to $45 \%$. However, this relationship is not so obvious in the case of $\mathrm{OH}$ treatments, particularly when CUT of $10 \mathrm{~s}$ and electric fields of $12 \mathrm{~V} \mathrm{~cm}^{-1}$ are combined. In this case, a decrease in solubility from 90 to $50 \%$ is only followed by an increase in size only from 90 to $120 \mathrm{~nm}$.

\section{Multivariate Analysis}

Principal component analysis (PCA) was performed to identify a global pattern in denaturation behavior of WPI under treatments applied by linking all stages discussed above-i.e., unfolding and exposure of SH groups, loss of protein solubility, and formation of protein aggregates. Figure 5 shows the 
Fig. 3 Aggregation kinetics of WPI solutions heated at $90{ }^{\circ} \mathrm{C}$ under conventional $\left(0 \mathrm{~V} \mathrm{~cm}^{-1}\right)$ and ohmic heating, described by a second-order polynomial kinetic model (dashed curves)

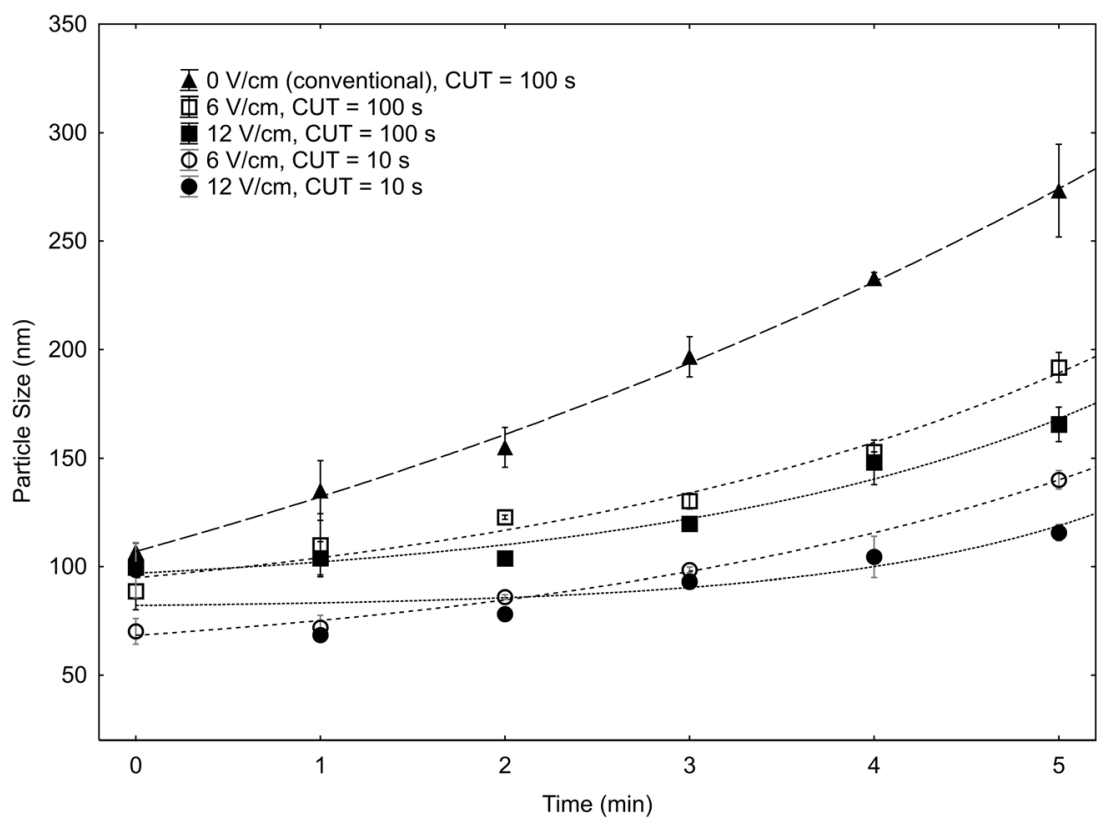

projection of cases (i.e., different treated samples) and variables (i.e., properties measured) from PCA. Each PCA case is identified by a letter corresponding to the type of treatment (i.e., 0,6 , and $12 \mathrm{~V} \mathrm{~cm}^{-1}$ ) and a number with correspondence with holding time of thermal treatments applied (from 0 to $5 \mathrm{~min}$ ) as follows: $\mathrm{U}$, unheated; $\mathrm{A}, 0 \mathrm{~V} \mathrm{~cm}^{-1}$ and CUT of $100 \mathrm{~s} ; \mathrm{B}, 6 \mathrm{~V} \mathrm{~cm}^{-1}$ and CUT of $100 \mathrm{~s} ; \mathrm{C}, 12 \mathrm{~V} \mathrm{~cm}^{-1}$ and CUT of $100 \mathrm{~s} ; \mathrm{D}, 6 \mathrm{~V} \mathrm{~cm}^{-1}$ and CUT of $10 \mathrm{~s}$; and E, $12 \mathrm{~V} \mathrm{~cm}^{-1}$ and CUT of $10 \mathrm{~s}$. For example, case D5 corresponds to a treatment in which an electric field of $6 \mathrm{~V} \mathrm{~cm}^{-1}$, a CUT of $10 \mathrm{~s}$, and a holding time of $5 \mathrm{~min}$ were applied.

According to PCA, the two main principal components, the first (horizontal axis) and second (vertical axis), accounted for $96.5 \%$ of the variability found in measured data. Hence, the reduction of the analysis to a bivariate dimension is satisfactory. From the projection of variables (see insertion of Fig. 5), it is possible to confirm that the increase of particle size and turbidity are well correlated and mainly responsible for the variability of data along the horizontal axis. Free $\mathrm{SH}$

Table 1 Kinetic parameters derived from the empirical model that was used to follow whey protein aggregation during heating at $90^{\circ} \mathrm{C}$ for $5 \mathrm{~min}$ at different electric field intensities

\begin{tabular}{llllll}
\hline Electric field $\left(\mathrm{V} \mathrm{cm}^{-1}\right)$ & CUT $(\mathrm{s})$ & $a(\mathrm{~nm})$ & $b(\mathrm{~nm})$ & $K\left(\mathrm{~min}^{-1}\right)$ & $R^{2}$ \\
\hline 0 & 100 & $178.24^{\mathrm{a}}$ & $107.0^{\mathrm{a}}$ & $0.1323^{\mathrm{a}}$ & 0.9972 \\
6 & 100 & $25.82^{\mathrm{b}}$ & $94.8^{\mathrm{a}, \mathrm{b}}$ & $0.3077^{\mathrm{a}}$ & 0.9776 \\
6 & 10 & $18.6^{\mathrm{b}}$ & $68.4^{\mathrm{b}}$ & $0.3158^{\mathrm{a}}$ & 0.9950 \\
12 & 100 & $10.1^{\mathrm{b}}$ & $96.9^{\mathrm{a}}$ & $0.4173^{\mathrm{a}}$ & 0.9674 \\
12 & 10 & $1.2^{\mathrm{b}}$ & $82.2^{\mathrm{a}, \mathrm{b}}$ & $0.6904^{\mathrm{a}}$ & 0.6130 \\
\hline
\end{tabular}

For each column, different letters correspond to statistically significant differences $(p<0.05)$ measurements are positively correlated with turbidity and aggregation, while contents of native protein are negatively correlated. These correlations are in agreement with thermal denaturation pathways of whey protein: unfolding and exposure of free SH groups determine protein aggregation, which in turn is physically apparent by the increase of solution turbidity or loss of protein solubility. From the cases projected in Fig. 5, it is possible to distinguish three major groups represented by their corresponding $95 \%$ confidence ellipses, namely: (1) unheated samples, (2) samples conventionally heated (thus without the presence of an electric field $-0 \mathrm{~V} \mathrm{~cm}^{-1}$ ), and (3) OH-treated samples at 6 and $12 \mathrm{~V} \mathrm{~cm}^{-1}$ with different CUT. Treated samples at $0 \mathrm{~V} \mathrm{~cm}^{-1}$ are more spread along the horizontal axis (factor 1), thus explaining $88 \%$ of the variability found in the first component of PCA. Longer heating times combined with conventional heating treatments $\left(\right.$ at $0 \mathrm{~V} \mathrm{~cm}^{-1}$ ) enhanced the increase of turbidity and aggregation of whey proteins - thus contributing to the high variability found in measured data in the first component (i.e., $88.7 \%$ ). Conversely, the second component (factor 2) exhibited $8.8 \%$ of the observed variability and described the influence of $\mathrm{OH}$ treatments applied, being the most part of the cases differentiated by their contents of native (or soluble) protein and free $\mathrm{SH}$. Increase of particle size and turbidity were less favored under $\mathrm{OH}$. Overall, the multivariate algorithm showed that the thermal denaturation behavior of whey proteins under $\mathrm{OH}$ can be distinguished from conventional thermal heating either by the presence of electric fields or by the ability to change the kinetics of the thermal process applied. A fast $\mathrm{OH}$ process contributes to less unfolding and loss of protein solubility during early stages of heating, while the presence of electric fields seems to change the way how denatured protein particles aggregate with each other. Previous publications 
Fig. 4 Relationship between protein solubility (\%) and particle size $(\mathrm{nm})$; the smoothed curve represents the predicted values of the kinetic model, estimated by non-linear regression analysis for the treatment at $0 \mathrm{~V} \mathrm{~cm}^{-1}$

$\left(R^{2}=0.95\right)$, with the corresponding $95 \%$ upper and lower confidence levels (dashed lines)

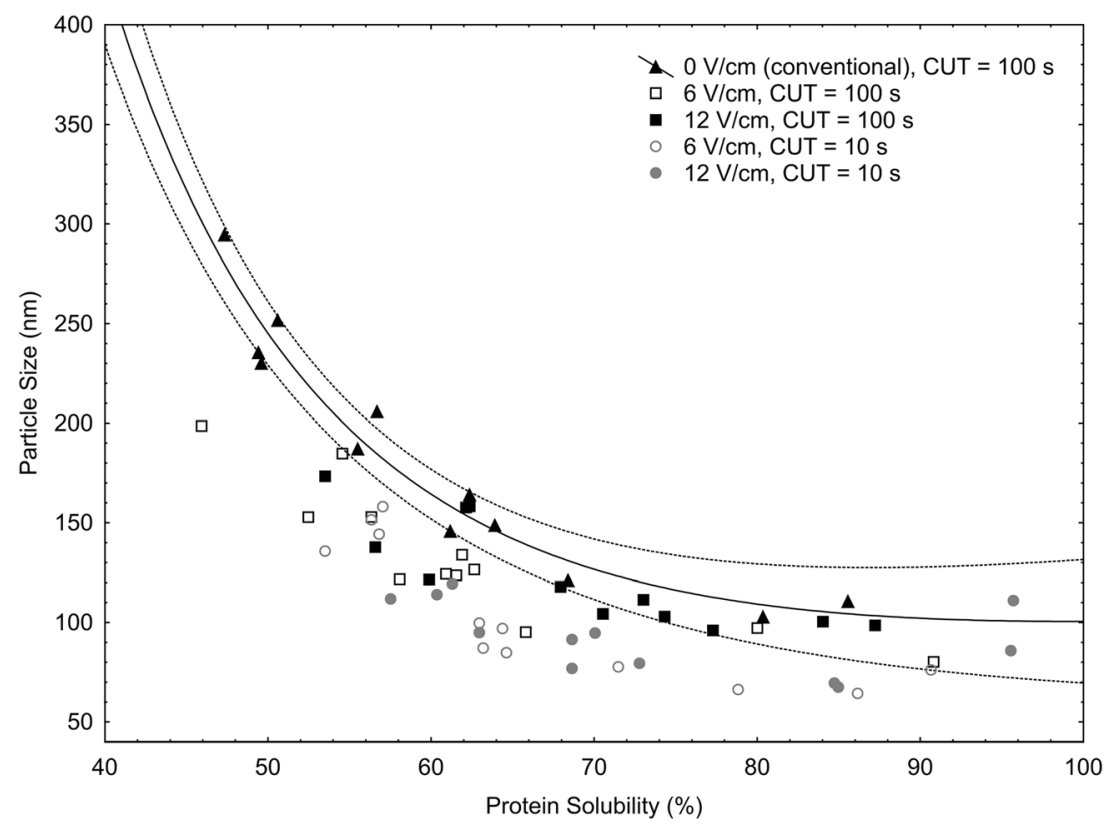

emphasize the non-thermal effects of $\mathrm{OH}$ on whey protein aggregation mechanisms (Pereira et al. 2010; Pereira et al. 2011; Rodrigues et al. 2015), which may be linked to the following aspects: conformational disturbances on tertiary protein structure; reorientation of hydrophobic clusters occurring in the protein structure; modification of the molecular environment due to the increased number of ions, and their different distributions around the protein molecules; and splitting of large protein aggregates, thus enhancing the formation of small particles. All these are hypotheses that need further experimentation. To our knowledge, the way electric fields interact at the molecular level with individual whey proteins may be rather complex. Aggregation kinetics (see "Aggregation") suggest that the presence of an electric field during heating changes the number as well as the shape or the network of protein aggregates.

\section{TEM}

To shed light onto the microstructure of the protein aggregates formed, samples treated by $\mathrm{OH}$ for $5 \mathrm{~min}$ at $90{ }^{\circ} \mathrm{C}$ using a CUT of $10 \mathrm{~s}$, under the application of different electric field intensities ( 6 or $12 \mathrm{~V} \mathrm{~cm}^{-1}$ ), were observed under TEM. These samples were chosen for TEM imaging because they differed
Fig. 5 Principal component analysis of measurements performed in unheated WPI (control) and WPI heated at $90{ }^{\circ} \mathrm{C}$ under conventional $\left(0 \mathrm{~V} \mathrm{~cm}^{-1}\right)$ and ohmic heating ( 6 and $\left.12 \mathrm{~V} \mathrm{~cm}^{-1}\right)$. Figure insert shows the projection and correlations between variables measured, namely free $\mathrm{SH}$, aggregation (i.e., size), protein solubility (i.e., native protein contents), and turbidity

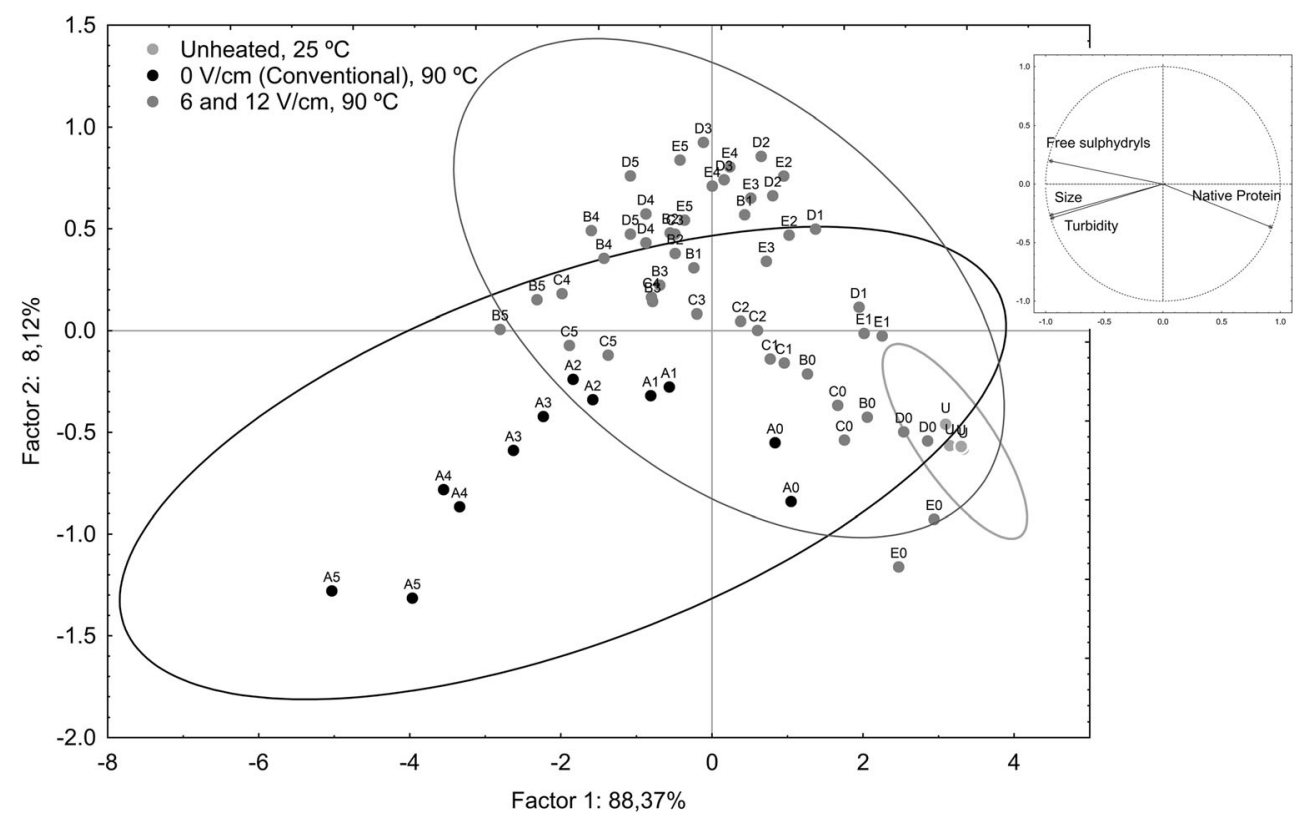


more significantly in terms of denaturation and aggregation behavior when compared with samples heated conventionally. Figure 6 shows TEM micrographs with typical fine-stranded structures composed of fine nanometer networks, which are known to occur at low ionic strength and $\mathrm{pH}$ values far from the $\mathrm{pI}$, due to the dominance of intermolecular electrostatic bonds (Ikeda and Morris 2002; Ramos et al. 2014; Schuster et al. 2014). For the case of $\mathrm{OH}$ treatments, visual inspection of the micrographs shows a more open structure with some levels of protein aggregation, when compared with the denser structure of the sample treated conventionally. Differences towards conventional samples were somehow expected due to different thermal histories applied. Under conventional treatment, protein aggregation was sufficient to promote growth of the protein clusters, thus turning the initial solution into a gel-like network. In the case of the $\mathrm{OH}$ treatments, TEM micrographs revealed the existence of short, defined small fibril aggregates. This is possibly related with the fact that when fine strands of $\beta$-lg are formed under neutral $\mathrm{pH}$, they can be flexible and longer, while those formed at acidic $\mathrm{pH}$ appear to be stiff and short (Ikeda and Morris 2002). Interestingly, in the case of $\mathrm{OH}$, the size of these fibrils seems to be affected only by the intensity of the electric field applied, once thermal histories among the treatments were made identical.

Particle size and shape distributions were determined directly from TEM micrographs using the ImageJ software particle analysis tool. In order to provide statistically meaningful particle size distributions (PSD), a minimum population of 100 particles was tracked and analyzed (Gontard et al. 2011; Sullivan et al. 2014). The detection of particles in a TEM image was performed as described by Gontard et al. (2011). Background pixels from TEM pictures were removed, and a binary image was obtained. Accuracy steps were then made to smooth the boundaries by removing small protrusions and regions smaller than the size of the expected protein aggregates (radius $<5 \mathrm{~nm}$ ). As a result of the particle analysis process, outlines of particles found on the binary image were overlaid on the original image to visually confirm accurate detection of protein aggregates. PSD was calculated through the area of measured particles, while a circularity distribution (CD) was also calculated to infer about the shape of the observed protein aggregates. Circularity is a measure of how circular the shape is, being defined in the software as $4 \pi$ (area/perimeter2)-i.e., a circularity of 1 indicates a perfect circle and as its value approaches 0 , it indicates an increasingly elongated shape (Jensen et al. 2010).

Figure 7a, b shows PSD and CD of the identified aggregates, respectively. The lognormal distribution provided the best description of the protein aggregates' size. When $\mathrm{OH}$ treatments were compared with each other, it was possible to observe that electric fields at $12 \mathrm{~V} \mathrm{~cm}^{-1}$ provided higher number of particles with areas ranging from 200 to $500 \mathrm{~nm}^{2}$, while treatments at $6 \mathrm{~V} \mathrm{~cm}^{-1}$ provided higher number of particles with areas above $500 \mathrm{~nm}^{2}$. These results agree with those from the aforementioned DLS measurements, showing that $\mathrm{OH}$ at $12 \mathrm{~V} \mathrm{~cm}^{-1}$ determines particles with a lower $Z$-average value. This value resulting from DLS measurement corresponds to an intensity-weighed value sensitive to any larger size species in the sample, thus being particularly significant for aggregated samples or for broad, polydisperse non-homogeneous samples (Nobbmann and Morfesis 2009). In this case, the high number of aggregates with areas above $500 \mathrm{~nm}^{2}$ found in samples treated at $6 \mathrm{~V} \mathrm{~cm}^{-1}$ may have been responsible for the high $Z$-values found during DLS measurements. With regard to $\mathrm{CD}$, it is important to note that different $\mathrm{OH}$ treatments provided nearly identical distributions with a high number of observations being noticed for particles with circularity ranging from 0.2 to 0.5 . This means that particle shape is mainly characterized by a linear-like structure, thus confirming the visual inspection of the micrographs. There is a recognition that $\beta$-lg could form fibrils when heated at low $\mathrm{pH}$ and low ionic strength; $\beta$-lg gels with a fine-stranded microstructure can be made at $\mathrm{pH}<4$ (Langton and Hermansson 1992). It is reported that far below proteins' $\mathrm{pI}$ (and also above), aggregates of pure $\beta-\lg$ solutions at $1 \%$ are characterized by a worm- or fibrillar-like structure, instead of a spherical one (Mezzenga and Fischer 2013; Schmitt et al. 2009). Several techniques have been reviewed for the production $\beta$-lg or WPI fibrils (Loveday et al. 2012). However, the most common method relies on prolonged heating (up to $20 \mathrm{~h}$ ), at $\mathrm{pH} 2$ and low ionic strength (Bolder et al. 2006; Ikeda and Morris 2002; Loveday et al. 2012). The need for a specific hydrolysis step has been also discussed as a way to enhance fibril

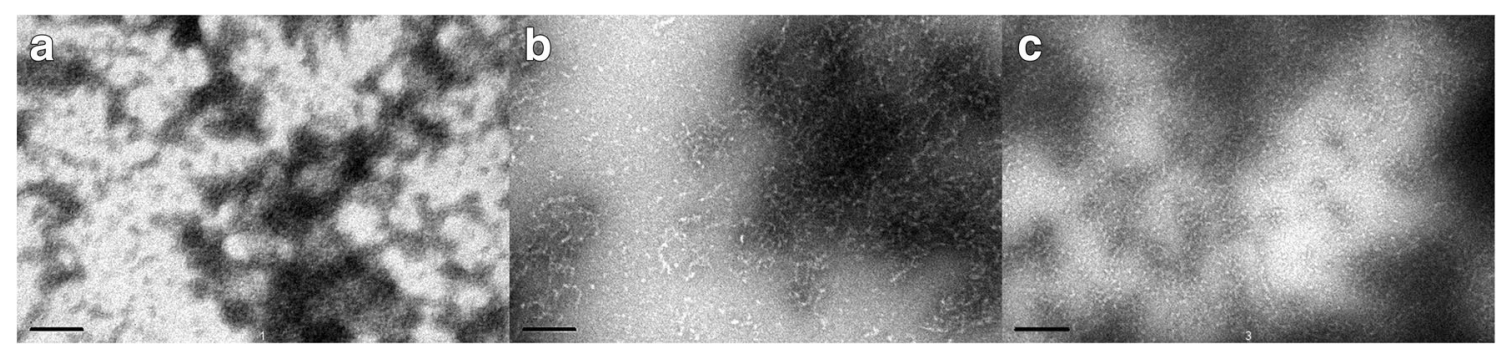

Fig. 6 TEM micrographs of MEF-treated WPI solutions: a conventional heating $\left(0 \mathrm{~V} \mathrm{~cm}^{-1}\right)$; b OH at $6 \mathrm{~V} \mathrm{~cm}^{-1}, \mathrm{CUT}=10 \mathrm{~s}$; and $\mathbf{c} \mathrm{OH}$ at $12 \mathrm{~V} \mathrm{~cm}^{-1}$, CUT $=10$ s. Black scale bars correspond to $200 \mathrm{~nm}$ 
a

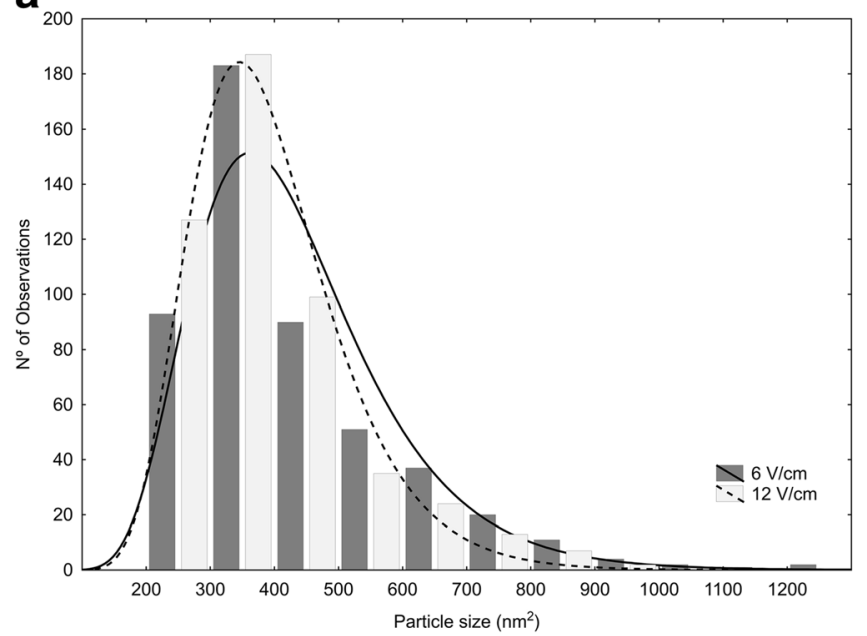

b

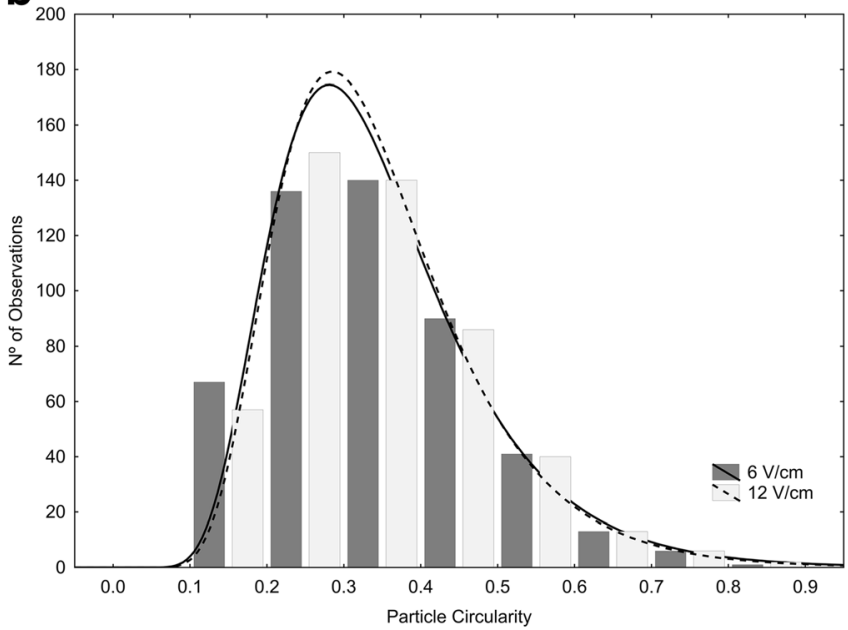

Fig. 7 Histograms of a particle size (i.e., area measurement) distributions and $\mathbf{b}$ circularity distributions of WPI solutions after OH treatments at 6 and $12 \mathrm{~V} \mathrm{~cm}^{-1}$ calculated from TEM images. Dashed and bold lines correspond to a lognormal fitting

formation (Bolder et al. 2007). In this study, OH treatments performed in WPI solutions with a relatively high protein concentration (i.e., $3 \%)$ and salt $\left(\sim 0.1 \mathrm{~mol} \mathrm{~L}^{-1}\right)$ allowed individualization of linear protein aggregates through TEM imaging, while in the absence of an electric field (conventional treatment), a gel-like protein network was developed instead, impairing detection of individual protein aggregates. This helps in explaining the differences found in estimated kinetic parameters that describe aggregation of WPI under $\mathrm{OH}$ treatments: fibrillar aggregates contribute to lower values found on size distribution and to a reduced protein aggregation, thus avoiding gel network formation when compared with conventional treatments $\left(0 \mathrm{~V} \mathrm{~cm}^{-1}\right)$, even under identical thermal conditions. Recently, it has been shown that $\mathrm{OH}$ treatments can reduce unfolding and protein denaturation without impairing protein aggregation pathways. Conversion of bovine $\beta$-lg into fibril-like structures may occur when proteins are partially unfolded, and non-covalent interactions between denatured protein molecules are allowed (Hamada and Dobson 2002). In this sense, application of $\mathrm{OH}$ may have enhanced formation of short fibril aggregates evidenced by TEM imaging. Moreover, the non-thermal effects of $\mathrm{OH}$ seem to be also linked with conformational changes of secondary protein structures, by increasing the contents of $\beta$-sheet structures (Pereira et al., 2010) which have been recently associated with the formation of $\beta-\lg$ fibrils during heating at $80{ }^{\circ} \mathrm{C}$ or prolonged incubation with chemical denaturants (Kavanagh et al., 2000). Protein aggregates possessing a fibrillar structure have attracted attention in biomedical and materials science fields, as they may resemble amyloid aggregates implicated in protein misfolding disorders, also known as amyloidosis diseases, e.g., Alzheimer's, Creutzfeldt-Jakob, and Huntington's diseases (Chimon et al. 2007; Du et al.
2015; Hamada and Dobson 2002; Loveday et al. 2012). Results show that $\mathrm{OH}$ may have the potential to enhance $\beta$-lg fibril formation when performed under certain conditions aforementioned (such as prolonged heating at $\mathrm{pH}<3$ and low ionic strength), but this hypothesis needs to be further verified.

\section{Conclusions}

$\mathrm{OH}$ influences unfolding, denaturation, and aggregation kinetics of WPI proteins. Its capability of fast heating through the Joule effect, coupled with treatments under relatively low electrical field strength, contributed to a synergistic effect yielding WPI solutions with less protein aggregates and high amount of soluble proteins during early stages of heating. Multivariate analysis allowed to correlate all information collected during thermal treatments, differentiating treated samples into different clusters in accordance with the treatment applied and highlighting non-thermal effects of $\mathrm{OH}$ that still need to be further confirmed. Moreover, these results help when interpreting the effects of electric fields on whey protein systems recently reported. $\mathrm{OH}$ enhanced the production of linear structured protein aggregates, whose size seems to be affected by the intensity of the electric field applied. These protein aggregates resemble fibril aggregates, which have a recognized potential to form physical gels, acting as thickeners or gelling agents in foods, and can be also used for encapsulation of bioactive ingredients, thus increasing the nutritive value of the foods. OH appears to be an effective biotechnological tool that can be used to modulate WPI denaturation and thus produce protein aggregates with distinctive features. 
Acknowledgments The authors thank the Portuguese Foundation for Science and Technology (FCT) strategic project UID/BIO/04469/2013 unit, the project RECI/BBB-EBI/0179/2012 (FCOMP-01-0124FEDER-027462), and the project "BioInd - Biotechnology and Bioengineering for improved Industrial and Agro-Food processes" REF. NORTE-07-0124-FEDER-000028 co-funded by the Programa Operacional Regional do Norte (ON.2 - O Novo Norte), QREN, FEDER. The authors would like to acknowledge Rui Fernandes from the Institute for Molecular and Cell Biology (IBMC), University of Porto, for the assistance in taking the TEM pictures. The authors Ricardo N. Pereira and Oscar L. Ramos also acknowledge FCT for their post-doctoral grants with references SFRH/BPD/81887/2011 and SFRH/BPD/80766/2011, respectively.

Author Contributions The manuscript was written through contributions of all authors. All authors have given approval to the final version of the manuscript.

\section{References}

Anema, S. G., \& Li, Y. M. (2003). Association of denatured whey proteins with casein micelles in heated reconstituted skim milk and its effect on casein micelle size. Journal of Dairy Research, 70(1), 73 83. doi:10.1017/S0022029902005903.

Augustin, M. A. (2003). The role of microencapsulation in the development of functional dairy foods. Australian Journal of Dairy Technology, 58(2), 156-160.

Bhopatkar, D., Hamaker, B. R., \& Campanella, O. H. (2012). Micro to macro level structures of food materials. In B. Bhandari, \& Y. H. Roos (Eds.), Food materials science and engineering: WileyBlackwell.

Bolder, S. G., Hendrickx, H., Sagis, L. M. C., \& van der Linden, E. (2006). Fibril assemblies in aqueous whey protein mixtures. Journal of Agricultural and Food Chemistry, 54(12), 4229-4234. doi:10.1021/Jf060606s.

Bolder, S. G., Vasbinder, A. J., Sagis, L. M. C., \& van der Linden, E. (2007). Heat-induced whey protein isolate fibrils: conversion, hydrolysis, and disulphide bond formation. International Dairy Journal, 17(7), 846-853. doi:10.1016/j. idariyj.2006.10.002.

Bryant, C. M., \& McClements, D. J. (1998). Molecular basis of protein functionality with special consideration of cold-set gels derived from heat-denatured whey. Trends in Food Science \& Technology, 9(4), 143-151. doi:10.1016/S0924-2244(98)00031-4.

Chalker, J. M., Gunnoo, S. B., Boutureira, O., Gerstberger, S. C., Fernandez-Gonzalez, M., Bernardes, G. J. L., et al. (2011). Methods for converting cysteine to dehydroalanine on peptides and proteins. Chemical Science, 2(9), 1666-1676. doi:10.1039/ c1sc00185j.

Chen, L., \& Subirade, M. (2007). Effect of preparation conditions on the nutrient release properties of alginate-whey protein granular microspheres. European Journal of Pharmaceutics and Biopharmaceutics, 65(3), 354-362. doi:10.1016/j.ejpb.2006.10. 012 [Research Support, Non-U.S. Gov't].

Chen, L. Y., Remondetto, G. E., \& Subirade, M. (2006). Food protein-based materials as nutraceutical delivery systems. Trends in Food Science \& Technology, 17(5), 272-283. doi:10.1016/j.tifs.2005.12.011.

Chimon, S., Shaibat, M. A., Jones, C. R., Calero, D. C., Aizezi, B., \& Ishii, Y. (2007). Evidence of fibril-like [beta]-sheet structures in a neurotoxic amyloid intermediate of Alzheimer's [beta]-amyloid. [10.1038/nsmb1345]. Nat Struct Mol Biol, 14(12), 1157-1164 http://www.nature.com/nsmb/journal/v14/n12/suppinfo/ nsmb1345_S1.html.
Cornacchia, L., Forquenot de la Fortelle, C., \& Venema, P. (2014). Heatinduced aggregation of whey proteins in aqueous solutions below their isoelectric point. Journal of Agricultural and Food Chemistry, 62(3), 733-741. doi:10.1021/jf404456q.

Dalgleish, D. G., \& Banks, J. M. (1991). The formation of complexes between serum proteins and fat globules during heating of whole milk. Milchwissenschaft - Milk Science International, 46, 75-78.

De Alwis, A. A. P., \& Fryer, P. J. (1990). A finite-element analysis of heat generation and transfer during ohmic heating of food. Chemical Engineering Science, 45(6), 1547-1559. doi:10.1016/00092509(90)80006-z.

de Wit, J. N. (1998). Nutritional and functional characteristics of whey proteins in food products. Journal of Dairy Science, 81(3), 597-608. doi:10.3168/jds.S0022-0302(98)75613-9..

Dissanayake, M., Ramchandran, L., Donkor, O. N., \& Vasiljevic, T. (2013). Denaturation of whey proteins as a function of heat, $\mathrm{pH}$ and protein concentration. International Dairy Journal, 31(2), 93 99. doi:10.1016/j.idairyj.2013.02.002..

Du, W.-J., Guo, J.-J., Gao, M.-T., Hu, S.-Q., Dong, X.-Y., Han, Y.-F., et al. (2015). Brazilin inhibits amyloid [bgr]-protein fibrillogenesis, remodels amyloid fibrils and reduces amyloid cytotoxicity. [Article]. Sci. Rep., 5, doi:10.1038/srep07992 http://www. nature.com/srep/2015/150123/srep07992/abs/srep07992. html\#supplementary-information.

Ellman, G. L. (1959). Tissue sulfhydryl groups. Archives of Biochemistry and Biophysics, 82(1), 70-77. doi:10.1016/0003-9861(59)90090-6..

Foegeding, E. A. (2006). Food biophysics of protein gels: a challenge of nano and macroscopic proportions. Food Biophysics, 1(1), 41-50. doi:10.1007/s11483-005-9003-y.

Gontard, L. C., Ozkaya, D., \& Dunin-Borkowski, R. E. (2011). A simple algorithm for measuring particle size distributions on an uneven background from TEM images. Ultramicroscopy, 111(2), 101106. doi:10.1016/j.ultramic.2010.10.011.

Gordon, L., \& Pilosof, A. M. R. (2010). Application of high-intensity ultrasounds to control the size of whey proteins particles. Food Biophysics, 5(3), 203-210. doi:10.1007/s11483-010-9161-4.

Gunasekaran, S., Ko, S., \& Xiao, L. (2007). Use of whey proteins for encapsulation and controlled delivery applications. Journal of Food Engineering, 83(1), 31-40. doi:10.1016/j.jfoodeng.2006.11.001.

Hamada, D., \& Dobson, C. M. (2002). A kinetic study of $\beta$-lactoglobulin amyloid fibril formation promoted by urea. Protein Science, 11(10), 2417-2426. doi:10.1110/ps.0217702.

Hoffmann, M. A. M., Roefs, S. P. F. M., Verheul, M., VanMil, P. J. J. M., \& DeKruif, K. G. (1996). Aggregation of beta-lactoglobulin studied by in situ light scattering. Journal of Dairy Research, 63(3), 423-440.

Ikeda, S., \& Morris, V. J. (2002). Fine-stranded and particulate aggregates of heat-denatured whey proteins visualized by atomic force microscopy. Biomacromolecules, 3(2), 382-389. doi:10.1021/bm0156429.

Jensen, T., Dolatshahi-Pirouz, A., Foss, M., Baas, J., Lovmand, J., Duch, M., et al. (2010). Interaction of human mesenchymal stem cells with osteopontin coated hydroxyapatite surfaces. Colloids and Surfaces BBiointerfaces, 75(1), 186-193. doi:10.1016/j.colsurfb.2009.08.029.

Kavanagh, G. M., Clark, A. H., \& Ross-Murphy, S. B. (2000). Heatinduced gelation of globular proteins: part 3. Molecular studies on low pH $\beta$-lactoglobulin gels. Int J Biol Macromol, 28(1), 41-50. doi:10.1016/S0141-8130(00)00144-6..

Langton, M., \& Hermansson, A. M. (1992). Fine-stranded and particulate gels of beta-lactoglobulin and whey-protein at varying pH. Food Hydrocolloids, 5(6), 523-539.

Law, A. J. R., \& Leaver, J. (2000). Effect of pH on the thermal denaturation of whey proteins in milk. Journal of Agricultural and Food Chemistry, 48(3), 672-679.

Lefevre, T., \& Subirade, M. (2000). Molecular differences in the formation and structure of fine-stranded and particulate beta-lactoglobulin gels. Biopolymers, 54(7), 578-586. doi:10.1002/10970282(200012)54:7<578::Aid-Bip100>3.0.Co;2-2. 
Lefevre, T., Subirade, M., \& Pezolet, M. (2005). Molecular description of the formation and structure of plasticized globular protein films. Biomacromolecules, 6(6), 3209-3219. doi:10.1021/bm050540u Research Support, Non-U.S. Gov't].

Livney, Y. D. (2010). Milk proteins as vehicles for bioactives. Current Opinion in Colloid \& Interface Science, 15(1-2), 73-83. doi:10. 1016/j.cocis.2009.11.002.

Madureira, A. R., Pereira, C. I., Gomes, A. M. P., Pintado, M. E., \& Xavier Malcata, F. (2007). Bovine whey proteins - overview on their main biological properties. Food Research International, 40(10), 1197-1211. doi:10.1016/j.foodres.2007.07.005.

Mezzenga, R., \& Fischer, P. (2013). The self-assembly, aggregation and phase transitions of food protein systems in one, two and three dimensions. Reports on Progress in Physics, 76(4). doi:10.1088/ 0034-4885/76/4/046601.

Nicolai, T., Britten, M., \& Schmitt, C. (2011). $\beta$-Lactoglobulin and WPI aggregates: formation, structure and applications. Food Hydrocolloids, 25(8), 1945-1962. doi:10.1016/j.foodhyd.2011.02.006.

Nicolai, T., \& Durand, D. (2013). Controlled food protein aggregation for new functionality. Current Opinion in Colloid \& Interface Science, 18(4), 249-256. doi:10.1016/j.cocis.2013.03.001.

Nicorescu, I., Loisel, C., Vial, C., Riaublanc, A., Djelveh, G., Cuvelier, G., et al. (2008). Combined effect of dynamic heat treatment and ionic strength on denaturation and aggregation of whey proteinspart I. Food Research International, 41(7), 707-713. doi:10.1016/j. foodres.2008.05.003.

Nobbmann, U., \& Morfesis, A. (2009). Light scattering and nanoparticles. Materials Today, 12(5), 52-54. doi:10.1016/S1369-7021(09) 70164-6.

Patrick, P. S., \& Swaisgood, H. E. (1976). Sulfhydryl and disulfide groups in skim milk as affected by direct ultra-high-temperature heating and subsequent storage. Journal of Dairy Science, 59(4), 594 600. doi:10.3168/jds.S0022-0302(76)84246-4.

Pereira, R. N., Souza, B. W. S., Cerqueira, M. A., Teixeira, J. A., \& Vicente, A. A. (2010). Effects of electric fields on protein unfolding and aggregation: influence on edible films formation. Biomacromolecules, 11(11), 2912-2918. doi:10.1021/bm100681a.

Pereira, R. N., Teixeira, J. A., \& Vicente, A. A. (2011). Exploring the denaturation of whey proteins upon application of moderate electric fields: a kinetic and thermodynamic study. Journal of Agricultural and Food Chemistry, 59(21), 11589-11597. doi:10.1021/ Jf201727s.

Phan-Xuan, T., Durand, D., Nicolai, T., Donato, L., Schmitt, C., \& Bovetto, L. (2013). Tuning the structure of protein particles and gels with calcium or sodium ions. Biomacromolecules, 14(6), 19801989. doi:10.1021/bm400347d.

Prabakaran, S., \& Damodaran, S. (1997). Thermal unfolding of betalactoglobulin: characterization of initial unfolding events responsible for heat-induced aggregation. Journal of Agricultural and Food Chemistry, 45(11), 4303-4308. doi:10.1021/Jf970269a.

Qiu, Y., \& Park, K. (2012). Environment-sensitive hydrogels for drug delivery. Advanced Drug Delivery Reviews, 64, 4960. doi:10.1016/j.addr.2012.09.024.

Ramos, O. L., Pereira, R. N., Rodrigues, R., Teixeira, J. A., Vicente, A. A., \& Xavier Malcata, F. (2014). Physical effects upon whey protein aggregation for nano-coating production. Food Research International, 66(0), 344-355. doi:10.1016/j.foodres.2014.09.036.
Rodrigues, R. M., Martins, A. J., Ramos, O. L., Malcata, F. X., Teixeira, J. A., Vicente, A. A., et al. (2015). ). Influence of moderate electric fields on gelation of whey protein isolate. Food Hydrocolloids, 43(0), 329-339. doi:10.1016/j.foodhyd.2014.06.002.

Sava, N., Van der Plancken, I., Claeys, W., \& Hendrickx, M. (2005). The kinetics of heat-induced structural changes of beta-lactoglobulin. Journal of Dairy Science, 88(5), 1646-1653. doi:10.3168/jds. S0022-0302(05)72836-8 [Research Support, Non-U.S. Gov't].

Schmitt, C., Bovay, C., Vuilliomenet, A. M., Rouvet, M., Bovetto, L., Barbar, R., et al. (2009). Multiscale characterization of individualized beta-lactoglobulin microgels formed upon heat treatment under narrow $\mathrm{pH}$ range conditions. Langmuir, 25(14), 7899-7909. doi:10. 1021/la900501n.

Schuster, E., Hermansson, A. M., Ohgren, C., Rudemo, M., \& Loren, N. (2014). Interactions and diffusion in fine-stranded beta-lactoglobulin gels determined via FRAP and binding. Biophysical Journal, 106(1), 253-262. doi:10.1016/j.bpj.2013.11.2959.

Simon M. Loveday, Rao M. A. \& Singh, H. (2012). Food protein nanoparticles: formation, properties and applications. In: Bhesh Bhandari, \& Yrjö H. Roos (Eds.), Food materials science and engineering (1.Edition ed.): Wiley-Blackwell

Soos, M., Lattuada, M., \& Sefcik, J. (2009). Interpretation of light scattering and turbidity measurements in aggregated systems: effect of intra-cluster multiple-light scattering. Journal of Physical Chemistry B, 113(45), 14962-14970. doi:10.1021/Jp907284t.

Stading, M., \& Hermansson, A.-M. (1990). Viscoelastic behaviour of $\beta$ lactoglobulin gel structures. Food Hydrocolloids, 4(2), 121-135. doi:10.1016/S0268-005X(09)80013-1.

Stading, M., \& Hermansson, A.-M. (1991). Large deformation properties of $\beta$-lactoglobulin gel structures. Food Hydrocolloids, 5(4), 339352. doi:10.1016/S0268-005X(09)80046-5.

Stading, M., Langton, M., \& Hermansson, A.-M. (1992). Inhomogeneous fine-stranded $\beta$-lactoglobulin gels. Food Hydrocolloids, 6(5), 455470. doi:10.1016/S0268-005X(09)80031-3.

Stanciuc, N., Dumitrascu, L., Ardelean, A., Stanciu, S., \& Rapeanu, G. (2012). A kinetic study on the heat-induced changes of whey proteins concentrate at two $\mathrm{pH}$ values. Food and Bioprocess Technology, 5(6), 2160-2171. doi:10.1007/s11947-011-0590-y.

Stokes, J. R. (2012). Food biopolymer gels, microgel and nanogel structures, formation and rheology. In: Bhesh Bhandari, \& Yrjö H. Roos (Eds.), Food materials science and engineering (1.Edition ed.): Wiley-Blackwell

Sullivan, S. T., Tang, C., Kennedy, A., Talwar, S., \& Khan, S. A. (2014). Electrospinning and heat treatment of whey protein nanofibers. Food Hydrocolloids, 35, 36-50. doi:10.1016/j.foodhyd. 2013.07.023.

Tuan, P. X., Durand, D., Nicolai, T., Donato, L., Schmitt, C., \& Bovetto, L. (2011). On the crucial importance of the $\mathrm{pH}$ for the formation and self-stabilization of protein microgels and strands. Langmuir, 27(24), 15092-15101. doi:10.1021/La203357p.

Verheul, M., Roefs, S. P. F. M., \& de Kruif, K. G. (1998). Kinetics of heatinduced aggregation of beta-lactoglobulin. Journal of Agricultural and Food Chemistry, 46(3), 896-903.

Ziegler, J., Viehrig, C., Geimer, S., Rosch, P., \& Schwarzinger, S. (2006). Putative aggregation initiation sites in prion protein. FEBS Letters, 580(8), 2033-2040. doi:10.1016/j.febslet.2006.03.002. 